\title{
Density and characteristics of Green mussels (Perna viridis) in Percut Sei Tuan coastal, North Sumatra, Indonesia
}

\author{
IPANNA ENGGAR SUSETYA ${ }^{1,2}$, MOHAMMAD BASYUNI ${ }^{2,3, \bullet}$, DESRITA $^{1,2}$, ARIDA SUSILOWATI $^{2,3}$, \\ TADASHI KAJITA ${ }^{4}$ \\ ${ }^{1}$ Department of Aquatic Resources Management, Faculty of Agriculture, Universitas Sumatera Utara. Jl. Prof. A. Sofyan No. 3, Kampus USU Padang \\ Bulan, Medan 20155, North Sumatra, Indonesia \\ ${ }^{2}$ Center of Excellence for Mangrove, Universitas Sumatera Utara. J1. Prof. A. Sofyan No. 3, Kampus USU Padang Bulan, Medan 20155, North Sumatra, \\ Indonesia \\ ${ }^{3}$ Faculty of Forestry, Universitas Sumatera Utara. J1. Tri Dharma Ujung No 1, Kampus USU Padang Bulan, Medan 20155, North Sumatra, Indonesia. \\ Tel./fax.: +62-61-8220605, `email: m.basyuni@usu.ac.id \\ ${ }^{4}$ Iriomote Station, Tropical Biosphere Research Center, University of the Ryukyus, Taketomi, Okinawa, 907-1541, Japan
}

Manuscript received: 7 December 2020. Revision accepted: 26 January 2021.

\begin{abstract}
Susetya IE, Basyuni M, Desrita, Susilowati A, Kajita T. 2021. Density and characteristics of Green mussels (Perna viridis) in Percut Sei Tuan coastal, North Sumatra, Indonesia. Biodiversitas 22: 1043-1050. Percut Sei Tuan is a coastal area on the east coast of North Sumatra that has a lot of natural resources, and Green mussels (Perna viridis) are one of them. Green mussels are beneficially important for consumption, cultivation and bio-indication. This study was aimed to determine the density, habitats, growth pattern and frequency distribution of Green mussels. The physicochemical parameters of water, a substrate of the bottom waters, and the relationship of Green mussel density to water and substrate parameters were also assessed. The study was conducted in July-September 2020 through the development and mature stages of Green mussels. Determination of research stations was based on differences in characteristics. The research station was divided into 3, namely river, estuary, and sea areas. Sampling for Green mussels used a quadrant transect measuring 1 x $1 \mathrm{~m}$. Each station has three sampling points for Green mussels. Each point was sampled 3 times using quadrant transects. The results showed that the density of Green mussels at stations I, II, and III were $352 \mathrm{ind} / \mathrm{m}^{2}, 3 \mathrm{ind} / \mathrm{m}^{2}$, and 1 ind $/ \mathrm{m}^{2}$, respectively. The relationship between the length and weight of green shells shows that the growth was negative allometric. The water condition, seen from the physical, chemical, and substrate parameters, was still suitable for $P$. viridis. Water and substrate parameters that were positively related to the density of Green mussels were water temperature, nitrate, phosphate, C-organic, percentage of silt and clay. Parameters that were negatively related were salinity, $\mathrm{pH}$, and percentage of sand in the bottom substrate. The present study suggests that Station I was an appropriate area for the growth and reproduction of Green mussels due to the high Corganic content.
\end{abstract}

Keywords: Density, Green mussels, Percut Sei Tuan, Perna viridis

\section{INTRODUCTION}

Percut Sei Tuan is a coastal area located on the east coast of North Sumatra. As a coastal area, having a river with several tributaries. Percut Sei Tuan has a lot of potential natural resources. Along the brackish water rivers, estuaries and the coastline at Percut Sei Tuan, mangrove trees grow well. Mangrove species in the Percut Sei Tuan are Avicennia marina, Bruguiera cylindrica, Bruguiera sexangula, Excoecaria agallocha, Lumnitzera racemosa, Rhizophora apiculata, Avicennia alba, Nypa fruticans and Sonneratia alba with densities of $834 \mathrm{ind} / \mathrm{ha}$ (Ningsih et al. 2011). Various species of birds, fish, and aquatic invertebrates are also potential natural resources in this region. There are 33 waterbird species from the Order Charadriiformes and Ciconiiformes that were found in the Bagan Percut (Jumilawaty et al. 2011). Furthermore, Susilo and Wibowo (2016) reported the existence of 30 species of fish, and Amrul et al. (2016) found 13 species of macrozoobenthos consisting of 1 type of Bivalvia, 11 species of Gastropods and 1 species of Polychaeta in the waters of YAGASU (Yayasan Gajah Sumatera) Research
Station, Tanjung Rejo Village, Percut Sei Tuan District. The Green mussels are distributed in the tropical water of the Indo-Pacific region of Asia extending from Japan to New Guinea, and from the Persian Gulf to South Pacific Islands (Gobin et al. 2013; Soon and Ransangan 2016).

One species of Bivalvia that has great potential in Percut Sei Tuan is Green mussels (Perna viridis). These shells are a member of the phylum 'mollusc' from the family 'mytilidae' (Carpenter and Niem 1998). They are widely distributed in Indonesia, especially abundant in coastal waters, mangrove areas, and river estuaries (Cappenberg 2008). Green mussels is found abundant in March to July on tidal and subtidal areas, live in groups and are firmly attached by using byssus on substrates or hard objects such as wood, stone, and bamboo (Cappenberg 2008).

Green mussels have economic value because they are widely traded and consumed. Noor et al. (2019) reported that the meat of $P$. viridis is accustomed to human consumption and it is an important species in aquaculture. Green mussels are widely cultivated for their ability to survive and reproduce under high ecological pressure (Cappenberg 2008). These shellfish contain balanced 
essential and nonessential amino acids, vitamins, mineral nutrients and have a low level of cholesterol content (Chakraborty et al. 2016). It fulfills the important criteria to be a good bio-monitor namely its wide geographical distribution, sedentary lifestyle, reasonable abundance and availability throughout the year, easy identification and sampling, filter-feeding organisms, bio-accumulative and they have correlative properties with the average pollutants of the environment, tolerance to natural environmental fluctuations and pollution (Tanabe et al. 1987; Putri et al. 2012).

Currently, despite the importance of economical and ecological Green mussels, there is no previously related information regarding Green mussels in Percut Sei Tuan coastal, North Sumatra. This study, therefore, was aimed to investigate the habitat characteristics of Green mussels including density, habitat location, growth patterns, and their frequency distribution. In addition to this information related to Green mussels, this study was also designed to determine the condition physical and chemical of water parameters and substrate texture. The results of this study are expected to be used as the base-line data for the management of $P$. viridis in the Percut Sei Tuan coastal.

\section{MATERIALS AND METHODS}

\section{Study area}

The research was conducted from July to September 2020 during the development and mature stages of Green mussels in the waters of Percut Sei Tuan, North Sumatra, Indonesia. Green mussel sampling is conducted monthly at three different stations. The station is determined based on the different characteristics (Soon and Ransangan 2014), the first station is located on the Red River, Percut Sei Tuan. Around the Red River, mangrove trees were found. Station II is the estuarine area, while station III is an intertidal area that leads to the open sea (Figure 1). Identification, measurement of length and weight of Green mussels (Asaduzzaman et al. 2019; 2020; Putri et al. 2012; Shahbazi et al. 2010) were carried out at the Laboratory of Water Environment, Department of Aquatic Resources Management, Faculty of Agriculture, Universitas Sumatra Utara. Substrate analysis (Basyuni et al. 2018) was carried out at the Socfin Indonesia Laboratory. Nitrate and phosphate analysis (Citra et al. 2020) was carried out at the Medan Environmental Disease Control and Health Engineering Center, Medan.

\section{Procedures \\ Sampling study}

A sampling of Green mussels was carried out at low tide using a quadrant transect measuring $1 \mathrm{~m} \times 1 \mathrm{~m}$ (Ambarwati et al. 2016). The time of collecting mussels at low tide aimed to facilitate the sampling process. Samples of Green mussels were taken 3 (three) times at each station. Apart from collecting samples of Green mussels, other types of shells on the transect were also identified and counted. To identify the shells using an identification book of Dharma (2005). Furthermore, the mussels were taken to the laboratory to identify and measure their length and wet weight.
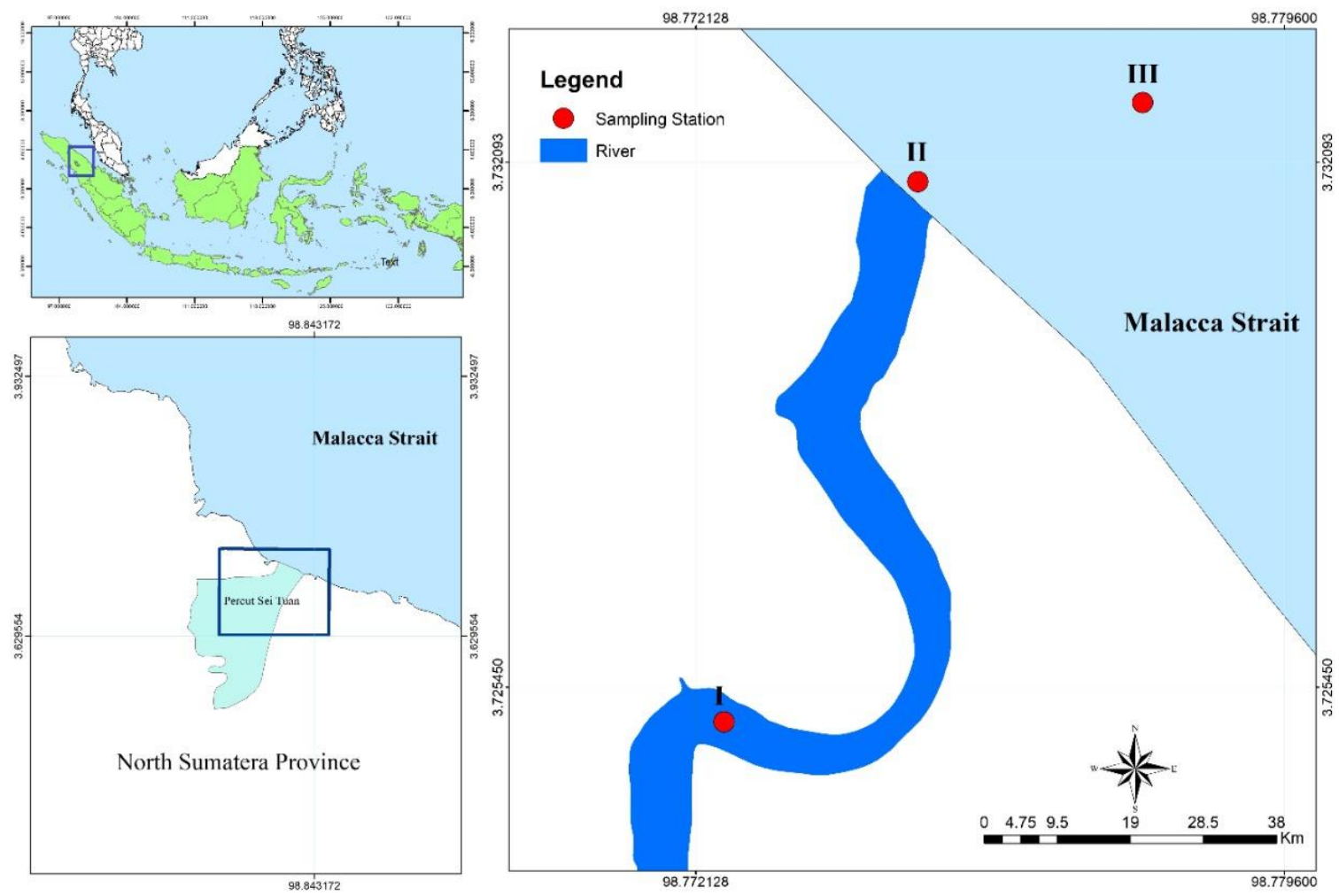

Figure 1. Locations of Green mussels (Perna viridis) sampling in the Percut Sei Tuan, Medan, North Sumatra. Station I ( $3^{\circ} 44^{\prime} 0.10^{\prime \prime} \mathrm{N}-$

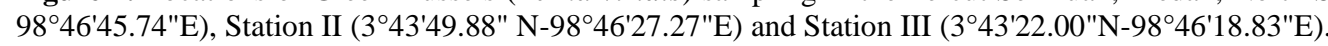




\section{Density of Perna viridis}

The density of Green mussels was calculated using the Krebs equation (1989). Density describes the condition of the Green mussel population. Density can also be expressed as the total number of individuals per area. The following is the formula (Krebs 1989) was followed to estimate the density of collected Green mussels:

$$
X=\frac{\Sigma n i}{A . S}
$$

Where,

$\mathrm{X}$ : Density (Individual $/ \mathrm{m}^{2}$ )

ni: The number of individual of species $i$

A: wide-area / wide one quadrant transect $\left(\mathrm{m}^{2}\right)$

$\mathrm{S}$ : number of sampling transects

The group of Green mussels shell length can be determined using the frequency distribution analysis. The frequency distribution of shell length is made by referring to the Sturges rule (Walpole 1992) by determining the number of classes, class width (class interval). The following is the formula (Walpole 1992) was used to assess the frequency distribution of shell length:

$$
\begin{aligned}
& \mathrm{k}=1+3,3 \log \mathrm{n} \\
& \text { Class interval }(\mathrm{i})=\mathrm{r} / \mathrm{k}
\end{aligned}
$$

Where,

$\mathrm{k}$ : number of class

$\mathrm{n}$ : the amount of data

$r$ : the difference between the maximum and minimum data values

\section{Measurements of physical and chemical parameters}

Physical and chemical parameters were measured in situ in the mangrove seawater using portable instruments. Temperature was measured using a portable thermometer. Dissolved oxygen (DO) was measured using a DO meter (Lutron DO-5510). $\mathrm{pH}$ was measured using a $\mathrm{pH}$ meter (EcoTestr pH 2, Eutech), and water current was measured manually using a stopwatch. Salinity was measured using a refractometer (Atago Master S28 M), and substrate texture as previously described (Basyuni et al. 2018). C-organic, nitrate, and phosphate were measured by standard methods for water analysis as previously reported (Citra et al. 2020).

\section{Length-weight relationships}

Analysis of the long-weight relationship of $P$. viridis used a linear regression test using the Microsoft Excel software and refers to the following formula (Effendie 2002; De Robertis and Williams 2008):

$$
\mathrm{W}=\mathrm{aL}^{\mathrm{b}}
$$

Where,

$\mathrm{W}$ : the total weight of the shells (gram)

$\mathrm{L}$ : the total lenght of the shells (mm)

a dan b: constant
The relationship between the total length parameter and the total shell weight can be seen from the value of $b$ which serves as an estimator of the closeness of the relationship between the two parameters.

$\mathrm{b}=3$, shows the isometric growth pattern (length growth with weight growth)

$\mathrm{b} \neq 3$, shows the allometric growth pattern divided into $\mathrm{b}>$ 3 , then allometric is positive (weight growth is more dominant) and $\mathrm{b}<3$, then allometric growth is negative (length growth is more dominant).

If the $b$ value,

$$
\mathrm{t}_{\text {count }}=\left|\frac{\mathrm{b}-3}{\mathrm{~s}_{\mathrm{b}}}\right|
$$

$\mathrm{S}_{\mathrm{b}}$ was the estimated standard error of the $\mathrm{b}$ value which was the root of $S^{2} b$. The value of $S^{2} b$ was calculated using the following formula.

$$
\mathrm{S}_{\mathrm{b}}{ }_{\mathrm{b}}=\frac{\mathrm{s}^{2}}{\sum_{\mathrm{i}=1}^{\mathrm{n}} \mathrm{x}^{2}{ }_{\mathrm{i}}-\frac{1}{\mathrm{n}}\left(\sum_{\mathrm{i}=1}^{\mathrm{n}} \mathrm{X}_{\mathrm{i}}\right)^{2}}
$$

The t-count was compared with the t-table value at the 95\% confidence interval. Decision was made if $t$-count $>t-$ table then reject the null hypothesis (H0) and if t-count $<\mathrm{t}-$ table accept the null hypothesis (H0) (Walpole 1992).

\section{Principal Component Analysis (PCA)}

This analysis was performed using the XL Stat software in order to determine the relationship between the density of Green mussels and the physical and chemical parameters of water and sediment (Basyuni et al. 2018; Noor et al. 2021). There were 12 factors analyzed in PCA, including density of Green mussels, temperature, salinity, water current, $\mathrm{pH}, \mathrm{DO}$, nitrate, phosphate, $\mathrm{C}$-organic, percentage of texture sand, silt, and clay. The distribution of characteristics of the physical and chemical parameters of water and sediment was also determined using this analysis.

\section{RESULTS AND DISCUSSION}

\section{The density of Green mussels (Perna viridis)}

Based on the analysis, it was found that the density of Green mussels in the waters of Percut Sei Tuan was 352 ind. $/ \mathrm{m}^{2}$ at station I. Station II had a density of Green mussels of 3 ind. $/ \mathrm{m}^{2}$, while station III had $1 \mathrm{ind} . / \mathrm{m}^{2}$ as shown in Figure 2. This result indicates station I have the highest density of Green mussels, while station III is the lowest. As shown in Figure 2 the difference in density occurred between station I and the other two stations, while stations II and III did not show a difference. The standard deviation values for stations I, II and III were 128,1.53 and 0.58 respectively. 


\section{Density of other species of bivalves}

This study found other species of bivalves at Station II dan III. At Station II species of Anadara gubernaculum and Anadara inaequivalvis were found. While in Station III detected more mussels species than those at Station II, such as A. gubernaculum, A. inaequivalvis, Atrina pectinata, Harvella plicataria and Mactra violacea. Density of each species at each station was presented in Table 1.

\section{Length-weight relationships}

Based on the analysis of the relationship between total length and total wet weight of Green mussels, we observed the equation $\mathrm{W}=0.0003 \mathrm{~L} 2.5673$ for Station $\mathrm{I}, \mathrm{W}=$ 0.0004L2.4574 at Station II, and W $=0.0003 \mathrm{~L} 2.6011$ for Station III (Figure 3). Through this equation we obtained $b$ value of 2.5673 for Station I, 2.4574 for Station II and 2.6011 for Station III. The value of $b$ observed less than 3 . The value of $b$ has been tested against the value 3 to find out that the value was equal to 3 or not the same as 3 . The values of t-count and t-table at Station I was 4.67 and 2.27. Station II had t-count and t-table of 5.04 and 2.28. The last station had t-count and $t_{\text {table }}$ of 2.88 and 2.37 . The test results showed that the $\mathrm{t}$-count for all stations is greater than t-table so that the first hypothesis which states that the growth pattern is allometric is accepted. Because the $b$ value obtained at all stations was less than three, the growth pattern of Green mussels in the Percut Sei Tuan area was allometric negative. The coefficient of determination at Stations I, II and III were 86.19\%, 86.26\% and $92.64 \%$, respectively (Table 3 ).

\section{Sample size of Green mussels (Perna viridis)}

The sample size was obtained from 377 Green mussels with a length ranged $23-62 \mathrm{~mm}$ as depicted in Table 2 . The size group mode was in the range of $43-47 \mathrm{~mm}$ at stations I and II. Station III had the size group mode in the range 48$52 \mathrm{~mm}$. Variety in length of Green mussels was distributed at station I because in all classes of length distribution there was the presence of these mussels.

Table 1. Density bivalves species at three stations (ind $/ \mathrm{m}^{2}$ )

\begin{tabular}{lccc}
\hline \multicolumn{1}{c}{ Species of bivalves } & Station I & Stasion II & Station II \\
\hline Anadara gubernaculum & 0 & 6 & 104 \\
Anadara inaequivalvis & 0 & 0 & 3 \\
Atrina pectinata & 0 & 0 & 2 \\
Harvella plicataria & 0 & 8 & 98 \\
Mactra violacea & 0 & 0 & 12 \\
Perna viridis & 352 & 0 & 0 \\
\hline
\end{tabular}

Table 2. Sample size of Green mussels (Perna viridis)

\begin{tabular}{cccc}
\hline Shell length $(\mathbf{m m})$ & Station I & Station II & Station III \\
\hline $23-27$ & 3 & 2 & \\
$28-32$ & 2 & & \\
$33-37$ & 4 & 2 & 4 \\
$38-42$ & 32 & 19 & 7 \\
$43-47$ & 124 & 35 & 9 \\
$48-52$ & 75 & 27 & 10 \\
$53-57$ & 18 & & \\
$58-62$ & 4 & & \\
Total number of individuals & 262 & 85 & 30 \\
\hline
\end{tabular}

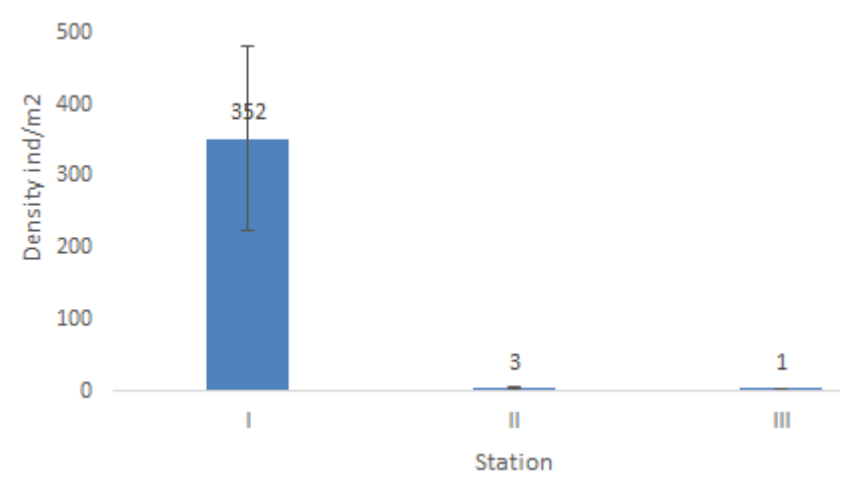

Figure 2. The density of Green mussels (Perna viridis) in different selected locations of the Percut Sei Tuan
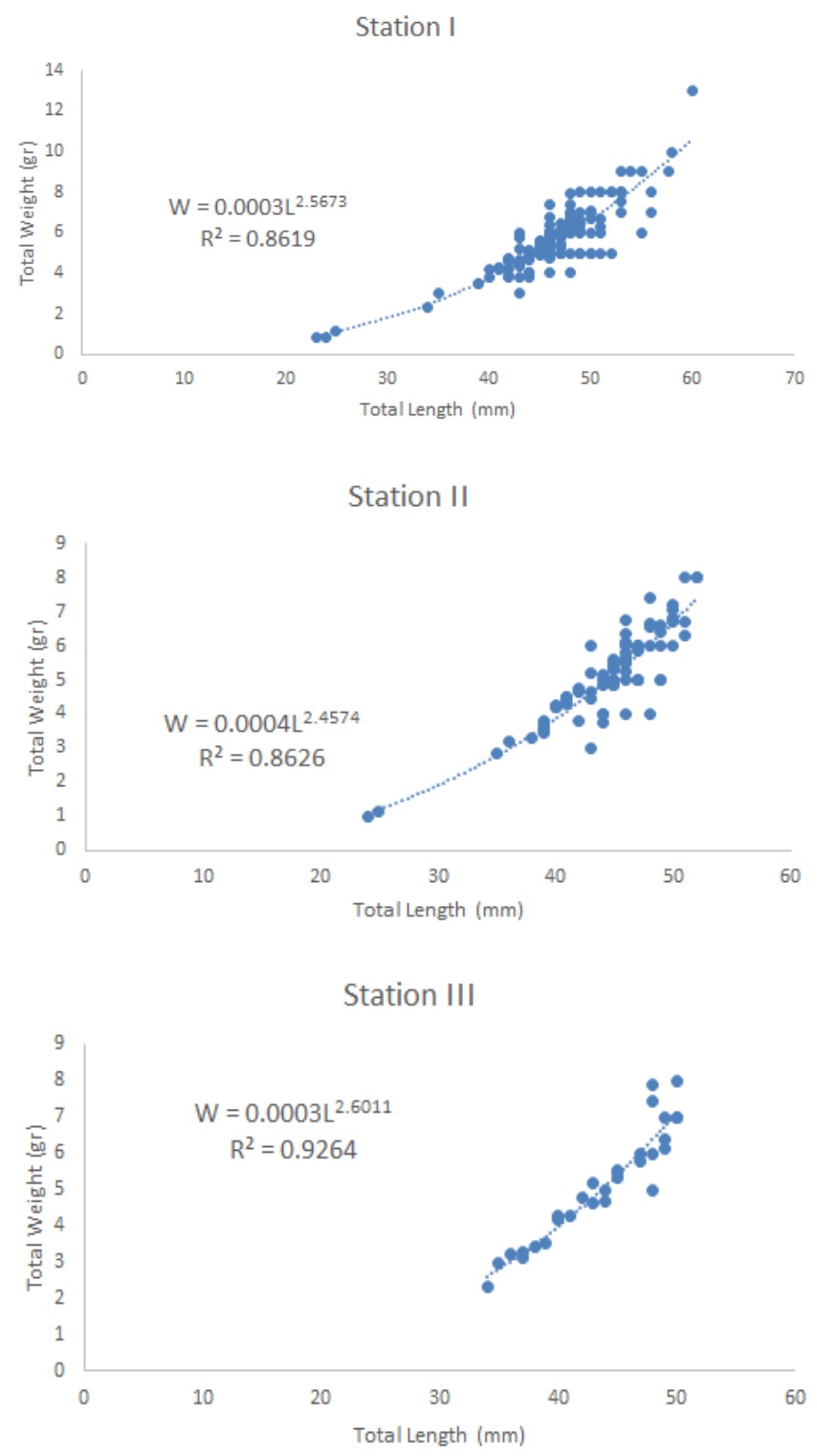

Figure 3. Regression analysis of the relationship between length and weight of Green mussels (Perna viridis) 


\section{Water parameters and substrate texture}

The results of measurements of physical and chemical parameters of water at the research location indicate that these parameters are still supportive of Green mussels $(P$. viridis). Complete explanation of water and substrate parameters can be seen in the discussion section. The range of water parameters measured during the study displayed in Table 3. The substrate texture was determined based on the percentage of sand, clay and silt obtained during the study. Station I has a substrate texture of sandy clay loam, clay loam and loam. The substrate textures at Station II are sandy loam and clay loam. Meanwhile, station III has substrate loam and clay loam textures.

\section{Principal component analysis}

Based on the analysis of the characteristics of Green mussels between the research stations, it was shown that the total performance on the first and second axes was $70,67 \%$. The first axis has a diversity of $48,66 \%$ and the second axis is $22,01 \%$. Formers of positive F1 and F2 positive axes are DO, silt, phosphate, clay and nitrate. Density of $P$. viridis, C-organic and temperature form the positive $\mathrm{F} 1$ and $\mathrm{F} 2$ axes. The negative $\mathrm{F} 1$ and $\mathrm{F} 2$ axes are formed by salinity and sand, while $\mathrm{pH}$ and water current form the negative F1 and F2 axes. Based on PCA results, the direction of the relationship between the density of Green mussels with water parameters and substrate texture can be shown from the formation of the angle. The density of Green mussels ( $P$. viridis) was positively related to temperature, nitrate, phosphate, C-organic, silt and clay which formed an angle of less than $90^{\circ}$. Parameters that have a negative relationship with the density of Green mussels are salinity, $\mathrm{DO}, \mathrm{pH}$, sand and water current (forming an angle of more than $90^{\circ}$ ). A very strong positive correlation is indicated by the formation of an angle close to $0^{\circ}$. In contrast, a very strong negative correlation is indicated by the formation of an angle close to $180^{\circ}$ (Figure 4).

Distribution of characteristics among physicochemical parameters was presented in Figure 5. The main component analysis showed that the characteristics of station III point 1 were nitrate, phosphate, percentage of silt and clay. High temperature and organic $\mathrm{C}$ were attribute of Station I point 1, Station I point 2 and Station II point 1. Further, Station I point 3 , Station II point 2, and Station II point 3 were categorized by high salinity and sand percentage. Finally, station III points 2 and 3 were characterized by high $\mathrm{pH}$ and current velocities (Figure 5).

\section{Discussion}

The observations during the research conducted in Sei Tuan Percut Waters, station I which shows the highest density of Green mussels is the brackish water river area with mangrove trees on the right and left sides. During the sampling in station I, only high density Green mussels have been found. Stations II and III, which are estuary and intertidal areas that lead to the sea, have a low density of Green mussels. In contrast to Station I, at Station II other species of shellfish were found, such as Anadara gubernaculum and Harvella plicataria. By contrast, at station III, other types of shellfish that are found more than station II, including A. gubernaculum, A. inaequivalvis, Atrina pectina, $H$. plicataria, and Mactra violacea.

The existence of local wisdom about the use of fishing gear can also cause differences in density from Green mussels. Trawl fishing gear is not allowed to operate in the river area by local residents. Trawling is only used in estuary and marine areas (Station II and III). Suprapto et al. (2006) suggested that the use of trawling can cause damage to the base substrate habitat which affects the community structure of both benthic organisms (composition and diversity).

Table 3. Water parameters and substrate conditions in the Percut Sei Tuan Waters, Medan

\begin{tabular}{lccc}
\hline \multicolumn{1}{c}{ Water Parameters } & Station I & Station II & Station III \\
\hline Temperature $\left({ }^{\circ} \mathrm{C}\right)$ & $31.65 \pm 0.5$ & $30.18 \pm 0.58$ & $30.50 \pm 0.27$ \\
Salinity $(\mathrm{ppt})$ & $25 \pm 6.08$ & $28.17 \pm 0.6$ & $25.82 \pm 2.83$ \\
Water Current $(\mathrm{m} / \mathrm{s})$ & $0.13 \pm 0.02$ & $0.05 \pm 0.01$ & $0.29 \pm 0.05$ \\
$\mathrm{pH}$ & $7.33 \pm 0.29$ & $7.50 \pm 0.17$ & $7.78 \pm 0.18$ \\
DO/Dissolve Oxygen $(\mathrm{mg} / \mathrm{L})$ & $7.01 \pm 0.37$ & $6.64 \pm 0.06$ & $8.43 \pm 0.36$ \\
Nitrate $(\mathrm{mg} / \mathrm{L})$ & $3.24 \pm 0.21$ & $2.63 \pm 0.18$ & $2.87 \pm 0.56$ \\
Phosphate $(\mathrm{mg} / \mathrm{L})$ & $2.07 \pm 1.22$ & $1.70 \pm 1.14$ & $1.66 \pm 1.09$ \\
C-Organic $(\%)$ & $2.06 \pm 0.4$ & $1.66 \pm 0.09$ & $1.42 \pm 0.38$ \\
Texture-sand $(\%)$ & $35.78 \pm 18.72$ & $38.55 \pm 22.57$ & $37.63 \pm 16.04$ \\
Texture-silt $(\%)$ & $39.24 \pm 15.41$ & $34.25 \pm 14.24$ & $38.83 \pm 10.24$ \\
Texture-clay $(\%)$ & $24.98 \pm 3.58$ & $27.21 \pm 8.79$ & $23.54 \pm 7.12$ \\
\hline
\end{tabular}

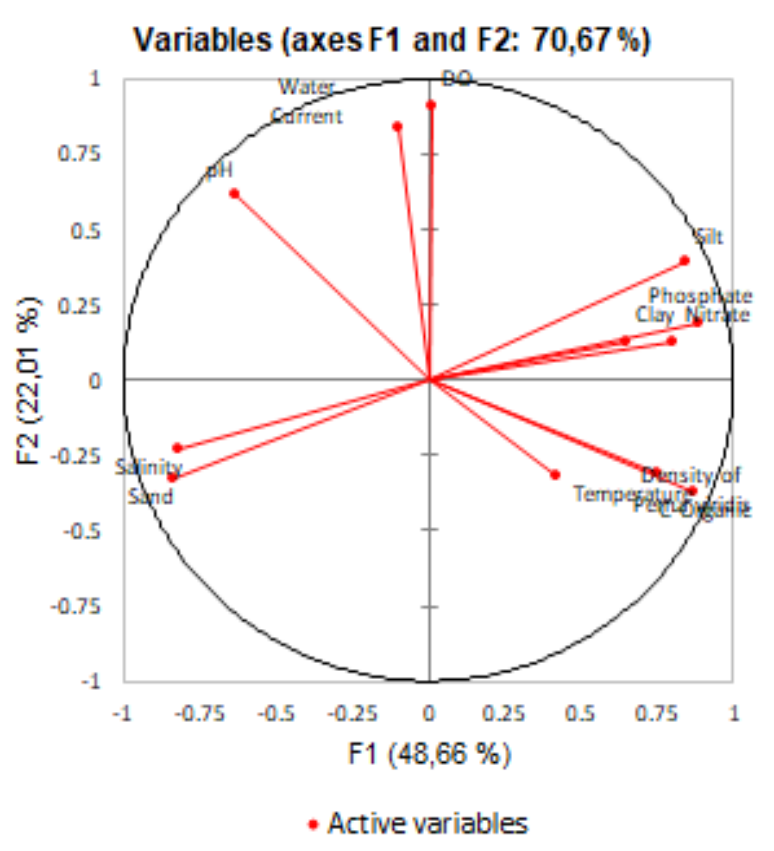

Figure 4. PCA variable showing relationship between the density of Green mussels (Perna viridis) and the physical and chemical parameters of water and sediment 


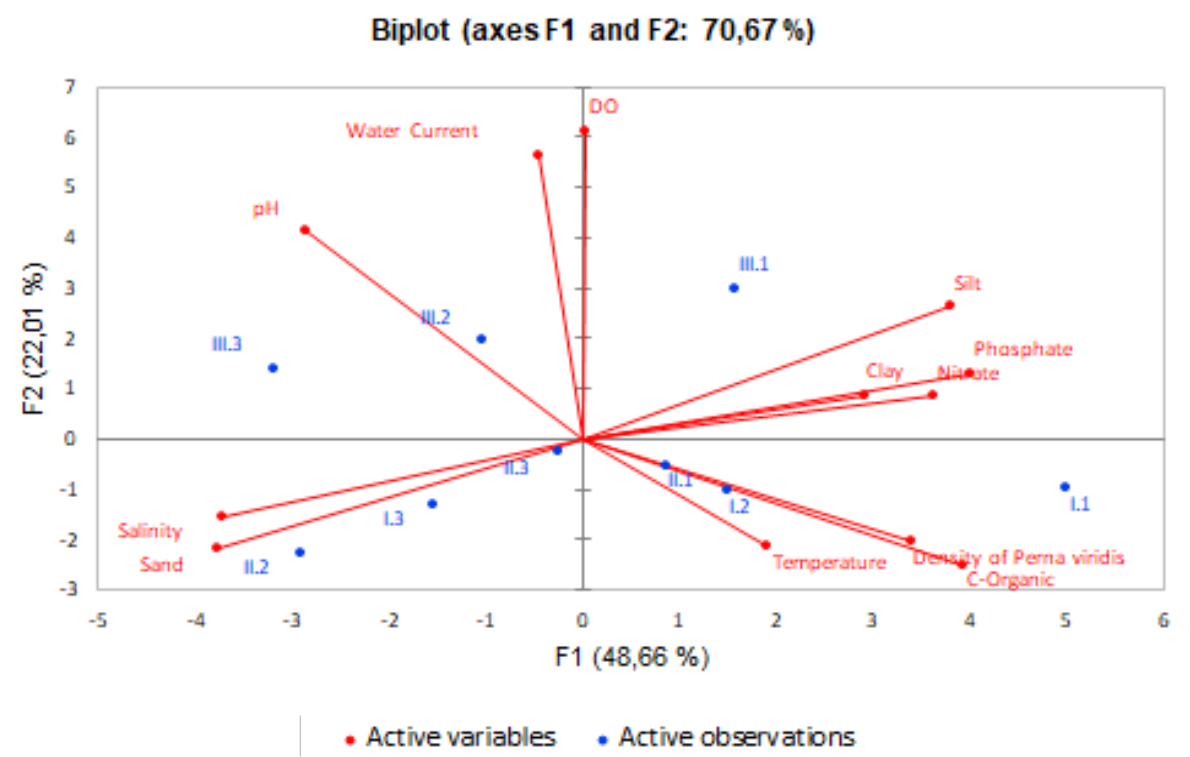

Figure 5. Distribution of chemical physics parameters

Density of Green mussels (P.viridis) at station I, which differed from stations II and III, one of the reasons was the absence of other species of shellfish living in this location The competition at station I only occurs in the same species, namely P.viridis. Station II which is also the second station with the highest density. There are only 2 species of shellfish as competitors in this location. Station III has the lowest density among the other two stations because the species of competitors that live in this location are more numerous and more diverse. This finding is in line with Lopez-Rocha et al. (2020) which has reported that the density and biomass of shellfish is controlled by a spatial distribution pattern with one of the factors that influence it is the competition.

Competitions both between inter-and intra-species, and the shell density can affect the form of growth of Green mussels (Alunno-Bruscia et al. 2001; Arribas et al. 2016; Donadi et al. 2013 ). The competition that occurs can be in the form of competition for space in high-density locations (Arribas et al. 2016) or in the form of competition for food (Donadi et al. 2013). With a high density and having to share food sources both between inter-and intra-species species, Green mussels adapted by increasing the length of the shell to get space and food. This circumstance was seen from the analysis of the relationship between length and total weight which has a value of $b<3$. This value means that the growth pattern of Green mussels ( $P$. viridis) in Percut Sei Tuan waters is allometric negative, which the increase in shell length is more dominant than the weight gain. Mussels tended to be narrower (flatter) at high density and at low food levels without implying physical interference (Alunno-Bruscia et al. 2001). Furthermore, Babarro et al. (2020) and (Asaduzzaman et al. 2020) showed that key environmental parameters such as food competition, substrate type, crowding, temperature, wave impact and predatory actions influences differences in shell morphology, shape, or thickness of bivalve mollusks (Large and Smee 2013). Cappenberg (2008) has reported that Green mussels also face many enemies in the habitat, including crab (Portunus sp), octopus (Octopus sp.), fish (Monacanthus sp.), and starfish which are the main and most active predators.

Individual size of $P$. viridis for all classes was only found at station I, while stations II and II were only in certain size classes. The maximum size found during the study, namely in class $58-62$, is only at station I. This indicates that this station is the best habitat that supports the life of $P$. viridis. Station I, which is a river area with mangrove trees growing around it, provides a lot of organic material input from the decomposition process of mangrove leaf litter. Supported by the measurement results of water parameters, the average range of C-organic, nitrate and phosphate content at this station is higher than the other stations. The principal component analysis results also have shown that the density of $P$. viridis is positively related to the content of $\mathrm{C}$-organic, nitrate and phosphate. Increasing the concentration of $\mathrm{C}$-organic, nitrate and phosphate as water nutrients will cause an increase in the abundance of phytoplankton and zooplankton. Green mussels are classified as sessile organisms whose life depends on the availability of zooplankton, phytoplankton and materials rich in organic content (Cappenberg 2008; Asaduzzaman et al. 2020). In addition, plankton is food source for bivalves influenced by nutrients especially nitrates and phosphates (Susetya et al. 2018; Asaduzzaman et al. 2020).

The length of Green mussels ranges from 23-62 mm (Al-Barwani et al. 2007) which consists of 8 classes with peaks in class 43-47 $\mathrm{mm}$ and located at Station 1 (river). The long frequency distribution shows the size distribution of Green mussels from juvenile, young, and adult. This finding showed that the distribution was dominated by 
mature Green mussels (Sreedevi et al. 2014; Rajagopal et al. 1998). Our study conducted from July-September, it is likely that during these months the Green mussels are still in the recruitment phase (Al-Barwani. et al 2007) and after that around January-February the Green mussels spawn (Al-Barwani et al. 2007).

Other water parameters that were also positively related to the density of green clams were temperature, silt and clay. The results of temperature measurements show that the temperatures at all stations are still in the range that supports $P$. viridis life (Asaduzzaman et al. 2019). The range of water temperature in the Percut Sei Tuan is between $29.73-32.17^{\circ} \mathrm{C}$. In accordance with the observations of Sagita et al. (2017) and Noor et al. (2021), the water temperature of Green mussel cultivation during the study ranged from $27.5^{\circ} \mathrm{C}-34.0^{\circ} \mathrm{C}$. The positive relationship between $P$. viridis density and temperature, especially at station I (points 1 and 2). This location is a relatively closed river location, therefore the water temperature in the river increases faster than the estuary and sea areas. The width of the river and the volume of river water which is lower than the width of the estuary and sea area (intertidal zone) cause the water temperature in the river to increase more rapidly (any ref for this statement).

Based on the PCA results, silt and clay also had a positive relationship with the density of Green mussels, while sand had a negative relationship. According to the grain size of the sediments, the order of the largest to the smallest grain sizes is sand, silt and clay, respectively (Refs). The larger the sediment grain size, the more difficult it is to bind organic material because it has a smaller surface area. Thus, silt and clay bind organic matter more easily than sand. The finer substrate texture contains higher levels of organic matter (Windusari et al. 2014; Susetya et al. 2018). The high percentage of silt and clay causes high $\mathrm{C}$-organic in the sediment which indirectly affects the density of Green mussels ( $P$. viridis). This is in accordance with Kurniawati et al. (2014), which states that the high density of mollusks (Telescopium telescopium) is also accompanied by high nutrient content in the mangrove ecosystem.

Salinity, $\mathrm{pH}$ and DO have a negative relationship with the density of Green mussels. This observation disagreed with previous report that salinity, clay, temperature, and DO supported the survival of macrozoobenthos in Lubuk Kertang mangrove forest (Basyuni et al. 2018). The density of Green mussels is low at stations that have a high salinity range such as at stations II (point 2 and 3) and III. In contrast to station I which is a brackish water river, stations II (estuary) and III (sea area or intertidal zone) are less affected by freshwater from the land. This is why the salinity at both stations is higher. According to Soon and Ransangan (2014), Green mussels can live in a wide range of salinity, namely 5.2-39.8 ppt but for optimum growth, it requires salinity in the range of 27-35 ppt (Soon and Ransangan 2016; Asaduzzaman et al. 2020). The range of $\mathrm{pH}$ values during the study was also still within normal limits for P. viridis. According to Haryanti et al. (2019), the optimum $\mathrm{pH}$ for Green mussels ranges from 6-8.2 (Asaduzzaman et al. 2020). Layugan et al. (2018) added that the suitable $\mathrm{pH}$ range for Green mussels is 7.5-8.41. The relationship between the density of Green mussels and $\mathrm{pH}$ is strong negative, which means that the density of Green mussels increases in locations with low $\mathrm{pH}$. The $\mathrm{pH}$ value is also negatively related to nitrate and phosphate, which are the indicators of the presence of a Green mussels food source, namely phytoplankton. Phytoplanktons utilize nitrate and phosphate as nutrients in carrying out photosynthesis. According to Effendie (2002), the nitrification process produces nitrate compounds that will end if the $\mathrm{pH}$ is low. In addition, Hamuna et al. (2018) stated that the low $\mathrm{pH}$ measurement results can occur because it is influenced by several factors, one of which is the photosynthetic activity of marine life. The last parameter that was negatively related to the density of Green mussels ( $P$. viridis) was DO. This circumstance occurred because the density of green shells is positively related to temperature, which means that at hightemperature locations the density also increases (Basyuni et al. 2018). When the temperature increases, it means that the DO of any water will decrease (Effendie 2002).

In conclusion, station I was a suitable area for the growth and reproduction of Green mussels due to the high C-organic content at the station. Characterized by a high density and a wide frequency distribution of the total shell length. The growth pattern of $P$. viridis in the Percut Sei Tuan waters is allometric negative. The water conditions seen from the physical and chemical parameters are also suitable for Green mussels life. Water and substrate parameters that were positively related to the density of Green mussels were water temperature, nitrate, phosphate, $\mathrm{C}$-organic, percentage of silt and clay. Parameters that were negatively related were salinity, $\mathrm{pH}, \mathrm{DO}$ and percentage of sand in the bottom substrate.

The present study suggested that management of fishery resources that could be provided is Green mussel cultivation. Station I has the potential to be used as a cultivation location. This condition is related to the high content of organic materials at the station, which is a natural food source for Green mussels. The local wisdom of the community to prohibit the use of trawl fishing gear at Station I is also the reason why this station is suitable for cultivation activities.

\section{ACKNOWLEDGEMENTS}

This work was supported by Directorate of Research and Community Service, Ministry of Research and Technology and National Research and Innovation Agency, Republic of Indonesia (No. 11/AMD/E1/KP.PTNB/2020) through the Basic Research Scheme 2020.

\section{REFERENCES}

Al-Barwani SM, Arshad A, Amin SN, Japar SB, Siraj SS, Yap CK. 2007. Population dynamics of the Green mussel Perna viridis from the high spat-fall coastal water of Malacca, Peninsular Malaysia. Fish Res 84 (2): $147-152$. 
Alunno-Bruscia M, Bourget E, Frechette M. 2001. Shell allometry and length-mass-density relationship for Mytilus edulis in an experimental food-regulated situation. Mar Ecol Prog Serr 219: 177-188.

Ambarwati R, Faizah U, Trimulyono G. 2016. Diversity and distribution of bivalves at Modung Beach, Bangkalan Madura Regency. Sains \& Matematika 5: 23-28. [Indonesian]

Amrul HMZN, Susilo F, Fauziah I. 2016. Diversity of macrozoobenthos species at the Aceh Sumatran Elephant Foundation Research Station (YAGASU), Tanjung Rejo Village, Percut Sei Tuan District, Del Serdang Regency, North Sumatra. Proceeding of Biology National Seminary (Implementation of Biological Research and Its Development in the Era of the Asean Economic Community) University of Sumatera Utara, Medan, 9 April 2016. [Indonesian]

Arribas LP, Bagur M, Soria AS, Gutierrez JL, Palomo MG. 2016 Competition between mussels at the rocky intertidal zone of $\mathrm{La}$ Loberia, Rio Negro, Argentina. Revista del Museo Argentino de Ciencias Naturales, Nueva Serie 18 (1): 1-7.

Asaduzzaman M, Noor AR, Rahman MM, Akter S, Hoque NF, Shakil A Wahab MA. 2019. Reproductive biology and ecology of the Green mussel Perna viridis: A multidisciplinary approach. Biology 8 (4) 88-103.

Asaduzzaman M, Akter S, Hoque NF, Shakil A, Noor AR, Akter MN Rahman MM. 2020. Multifaceted linkages among eco-physiological factors, seasonal plankton dynamics and selective feeding behavior of the Green mussel (Perna viridis) in the south-east coast of the Bay of Bengal. J Sea Res 164: 101933.

Babarro JMF, Filgueira R, Padín XA, Longa Portabales MA. 2020. A Novel Index of the Performance of Mytilus galloprovincialis to Improve Commercial Exploitationin Aquaculture. Front Mar Sci 7: 117

Basyuni M, Gultom K, Fitri A, Susetya IE, Wati R, Slamet B, Sulistiyono N, Balke T, Bunting P. 2018. Diversity and habitat characteristics of macrozoobenthos in the mangrove forest of Lubuk Kertang Village, North Sumatra. Biodiversitas 19 (1): 311-317.

Chakraborty K, Chakkalakal SJ, Joseph D, Asokan PK, Vijayan KK. 2016 Nutritional and Antioxidative Attributes of Green mussel (Perna viridis L.) from the Southwestern Coast of India. J Aquat Food Prod Technol 25: 968-985.

Cappenberg HAW. 2008. Some biological aspects of Green mussels Perna viridis Linnaeus 1758. Oseana 33: 33-40. [Indonesian]

Dharma B. 2005. Recent \& Fossil Indonesian Shells. Conch Books, Germany.

De Robertis A, Williams K. 2008. Weight-length relationships in fisheries studies: the standard allometric model should be applied with caution. Trans Am Fish Soc 137 (3): 707-719.

Donadi S, Heide TVD, Zee EMVD, Eklof JS, Koppel JVD, Weerman EJ, Piersma T, Olff H, Eriksson BK. 2013. Cross-habitat interaction among bivalve species control community structure on intertidal flats. Ecology 94: 489-498.

Effendie MI. 2002. Biologi Perikanan. Yayasan Pustaka Nusatama, Yogyakarta. [Indonesian]

Gobin J, Agard J, Madera J, Mohammed A. 2013. The Asian Green mussel Perna viridis (Linnaeus 1758): 20 years after its introduction in Trinidad and Tobago. Open J Mar Sci 3: 62-65.

Hamuna B, Tanjung RHR, Suwito, Maury HK dan Alianto. 2018. Study of Sea Water Quality and Pollution Index Based on Physical-Chemica Parameters in Depapre District Waters, Jayapura. Jurnal Ilmu Lingkungan 16: 35-43. [Indonesian]

Haryanti R, Fahrudin A, Susanto HA. 2019. Study on the suitability of Green mussel (Perna viridis) culture in North Sea Waters of Java, Ketapang Village, Tangerang District, Banten Province. J Aquaculture Fish Health 8: 184-190. [Indonesian]

Jumilawaty E, Mardiastuti A, Prasetyo LB, Mulyani YA. 2011. Waterbirds Diversity in Bagan Percut, Deli Serdang North Sumatra. Media Konservasi 16: 108-113. [Indonesian]

Krebs CJ. 1989. Ecological Methodology. University of British Columbia, Harper Collins Publishers, New York.
Kurniawati A, Bengen DG, Maddupa H. 2014. Characteristics of Telescopium telescopium on mangrove ecosystem at the Segara Anakan Lagoon, Cilacap District, Central Java. Bonorowo Wetlands 4 : 71-81.[Indonesian]

Large SI, Smee DL. 2013. Biogeographic variation in behavioral and morphological responses to predation risk. Oecologia 171 (4): 961969.

Layugan EA, Tabasin JPB, Alejos MS, Pidoy LE. 2018. growth performance of Green mussel Perna viridis transplanted in Buguey Lagoon, Philippines. Acta Sci Agric 2 : 43-47.

Ningsih SS, Widhiastuti R, Utomo B, Guslim. 2011. Inventory of mangrove forest as part of management effort in coastal area of Deli Serdang, North Sumatra. Bonorowo Wetlands 1: 58-69. [Indonesian]

Noor NM, Nursyam H, Widodo MS, Risjani Y. 2019. Biological aspects of Green mussels Perna viridis cultivated on raft culture in Pasaran coastal waters, Indonesia. AACL Bioflux 12: 448-456.

Noor AR, Shakil A, Hoque NF, Rahman MM, Akter S, Talukder A, AlNahid, Sam Wahab MA, Nahiduzzaman M, Rahman MJ, Asaduzzaman, M. 2021. Effect of eco-physiological factors on biometric traits of Green mussel Perna viridis cultured in the southeast coast of the Bay of Bengal, Bangladesh. Aquac Rep 19: 100562. DOI: 10.1016/j.aqrep.2020.100562.

Putri LSE, Prasetyo AD, Arifin Z. 2012. Green Mussel (Perna viridis L.) as bioindicator of heavy metals pollution at Kamal Estuary, Jakarta Bay, Indonesia. J Environ Res Dev 6: 1-8

Rajagopal S, Venugopalan VP, Nair KVK, Van der Velde G, Jenner HA, Den Hartog C. 1998. Reproduction, growth rate and culture potential of the Green mussel, Perna viridis (L.) in Edaiyur backwaters, east coast of India. Aquaculture 162 (3-4): 187-202.

Sagita A, Kurnia R, Sulistiono. 2017. Green mussel (Perna viridis L.) culture with different methods and densities in coastal waters Kuala Langsa, Aceh. Jurnal Riset Akuakultur 12: 57-68. [Indonesian]

Shahbazi A, Zakaria MP, Yap CK, Surif S, Bakhtiari AR, Chandru K, Bahry PS, Sakari M. 2010. Spatial distribution and sources of polycyclic aromatic hydrocarbons (PAHs) in Green mussels (Perna viridis) from coastal areas of Peninsular Malaysia: implications for source identification of perylene. Intl J Environ Anal Chem 90 (1): 14-30.

Sreedevi PR, Uthayakumar V, Jayakumar R, Ramasubramanian V. 2014. Influence of rearing water temperature on induced gonadal development and spawning behaviour of tropical Green mussel, Perna viridis. Asian Pac J Reprod 3 (3): 204-209.

Susetya IE, Desrita, Ginting EDD, Fauzan M, Yusni E and Saridu SA. 2018. Biodiversity of Bivalves in Tanjung Balai Asahan Waters, North Sumatra, Indonesia. Biodiversitas 19 (3) 1147-1153.

Susilo F, Wibowo B. 2016. Inventory of Fish Spesies in Yagasu Research Station, Tanjung Rejo, Percut Sei Tuan, Deli Serdang, North Sumatra. Jurnal Eksakta 2: 13-18. [Indonesian]

Soon TK, Ransangan J. 2014. A review of feeding behavior, growth, reproduction and aquaculture site selection for Green-lipped mussel, Perna viridis. Adv Biosci Biotechnol 5 : 462-469.

Soon TK, Ransangan J. 2016. Feasibility of Green mussel, Perna viridis farming in Marudu Bay, Malaysia. Aquacultur Rep 4: 130-135

Suprapto, Herlisman, Wagiyo K. 2006. Bottom water quality and abundance of benthic fauna in Arafura Sea. J Lit Perikanan Indonesia 12 (3): 211-217. [Indonesian]

Tanabe S, Tatsukawa R, Phillips DJ. 1987. Mussels as bioindicators of PCB pollution: A case study on uptake and release of PCB isomers and congeners in Green-lipped mussels (Perna viridis) in Hong Kong waters. Environ Pollut 47 (1): 41-62.

Windusari Y, Sarno, Saleh E, Hanum L. 2014. Substrate characteristics and its impact on distribution of mangrove species: a case study in Sungai Barong Kecil in The Sembillang National Park at Banyuasin, South Sumatra. J Biol Res 19: 82-86.

Walpole RE. 1992. Statistics Introduction $3^{\text {rd }}$ ed. Gramedia Pustaka Utama, Jakarta. [Indonesian] 